\title{
Analysis of the Nutrients and Microbiological Characteristics of the Indonesian Dadih As a Food Supplementation
}

\author{
Helmizar $^{1}$, Elya Yuswita ${ }^{1} \&$ Andani Eka Putra ${ }^{2}$ \\ ${ }^{1}$ Department of Nutrition, Faculty of Public Health, Andalas University, Padang, Indonesia \\ ${ }^{2}$ Department of Microbiology, Faculty of Medicine, Andalas University, Padang, Indonesia \\ Correspondence: Helmizar, Department of Nutrition, Faculty of Public Health, Andalas University, Padang, Jalan \\ Perintis Kemerdekaan Jati Padang, Padang 25144, Indonesia. E-mail: helmizar@ph.unand.ac.id
}

Received: September 27, 2018 Accepted: December 10, 2018 Online Published: December 23, 2018

doi:10.5539/gjhs.v11n1p155

URL: https://doi.org/10.5539/gjhs.v11n1p155

\begin{abstract}
Dadih, an Indonesia traditional fermented buffalo milk produced and consumed by the Minangkabau ethnic group in the province of West Sumatra, Indonesia, is considered to be beneficial to human health. The objective of this study is to found out the nutrient compositions and bacteriological characteristics of dadih collected from Tanah Datar and Agam districs in West Sumatera province, Indonesia. This study was initiated with the analysis of biochemical protein, lipid, moisture value, $\mathrm{pH}$, and titritable acidity contained in dadih. Bacteriological analysis has been conducted on total bacterial and total Acid Lactic Bacterial quantification. The study relveals that the total percentage of protein, lipid, moisture value, ash content, $\mathrm{pH}$, and titritable acidity of dadih from Tanah Datar respectively is $12.41 \pm 1.30,5.70 \pm 1.73,66.09 \pm 6.00,0.72 \pm 0.13,4.55 \pm 0.21,0.51 \pm 0.56$. Total percentage of protein, lipid, moisture value, ash content, $\mathrm{pH}$, and titritable acidity of dadih from Agam respectively is $10.89 \pm 2.55$, $18.00 \pm 14.65,61.94 \pm 20.18,1.14 \pm 0.79,4.33 \pm 0.46,1.70 \pm 0.21$. Dadih from Tanah Datar contains $1.9 \times 10^{7} \mathrm{CFU} / \mathrm{g}$ BAL and $2.3 \times 10^{7} \mathrm{CFU} / \mathrm{g}$ total bacteria. Ther study also shows that dadih from Agam contains $4.6 \times 10^{6} \mathrm{CFU} / \mathrm{g}$ BAL and $2.9 \times 10^{8} \mathrm{CFU} / \mathrm{g}$ total bacteria. The study concludes that there is not pathogenic bacteria in dadih from both Tanah Datar and Agam.
\end{abstract}

Keywords: nutrients, dadih, microbiological characteristics, food suplementation

\section{Introduction}

Dadih is a traditionally fermented buffalo milk produced and consumed by several communities of Minangkabau ethnic group. Fermentation of dadih occurs spontaneously at room temperature $\left(30^{\circ} \mathrm{C}\right)$ for two days after the curd has been poured into a bamboo tube and closed with banana leaves (Surono et al., 2008). Dadih contains two types of probiotic strains of Lactic Acid Bacteria, including E. faecium IS-27526. Dadih is very popular in several districts/cities in West Sumatra Province such as Agam, Bukittinggi, Solok, Lima Puluh Kota and Tanah Datar. Various lactic acid bacteria contained in dadih can inhibit or remove certain pathogenic bacteria, and can be used for further assessment, product development, and clinical intervention in humans (Putra et al., 2011). Sadly however, the consumption of dadih by the people, especially the youths, has dropped in recent years. In fact, most of the Minangkabau youths are unaware of the benefits of functional food products that are rich in probiotics such as dadih. Therefore, dadih needs to be reintroduced to the community with its distinctive appearance using bamboo containers as packaging. In general, the dadih produced by the people of West Sumatra is unpasteurized and the bamboo tubes used are often uncleaned. This process has been carried out from generation to generation by the local community, making it difficult to change the habits of the farmers.

The development of technology and science has helped the local government and related parties such as researchers to contribute to the progress and development of dadih by West Sumatran farmers. The training on dadih processing from start to finish in accordance with food safety standards is very beneficial to the local communities as it allows them to produce quality dadih. Improving the quality of dadih through better processing will certainly attract consumers. Dadih can have an impact on health as it contains a number of living microbial cells ranging between 106-108 cfu/g (Tannock, 1999), or 107-108 cfu/g of product in its probiotic product (Charterist et al., 1998). The presence of Lactic Acid Bacteria in dadih acts as a probiotic that can regulate the digestive tract ecosystem. The metabolites produced by this Lactic Acid Bacteria can inhibit the growth of pathogenic bacteria, improve the immune system, prevent constipation, reduce cholesterol, antimutagenic, 
anticarcinogenic, antivaginitis, and produce B vitamins and bacteriocin (Pato, 2003). These various benefits become the basis for using dadih as a supplement for the community members, especially pregnant women.

The consumption of dadih will be much efficient if it is accompanied by the consumption of zinc supplements to improve the nutritional status of mothers and babies. The supplementation of probiotic food sources with zinc to pregnant women can directly improve the nutritional status of infants, especially premature infants or low birth weight babies (Lutter \& Chaparro, 2009). Some dairy products have been reported to contain probiotic bacteria, and if consumed in sufficient quantities, they can be very beneficial to body health. Up to the present, intervention studies based on local food products such as dadih with zinc supplementation during pregnancy have not been well elaborated. In addition, information about the effects of dadih and zinc supplementation to pregnant women regarding their body's humoral immune response and their infant birth weight in Indonesia is very limited. Because pregnancy outcomes are affected by nutritional intervention during pregnancy, it is necessary to conduct research on food-based nutrition interventions and zinc supplementation to optimize maternal and child health. Giving nutritional intervention during pregnancy is also in line with efforts to support a key government program i.e., the Efforts to Improve Nutrition National Movement in the First 1000 Days of Life (1000 HPK). This study aims to determine the nutritional value and characteristics of dadih bacteria in West Sumatra, especially in Agam and Tanah Datar regions.

\section{Research Method and Material}

The material used in this study is dadih, a traditional fermented buffalo milk obtained from Agam and Tanah Datar regencies in West Sumatra Province. This research was conducted from November 2016 to June 2017 at the Laboratory of Biochemical Analysis and Microbiology of the Agricultural Technology Faculty, the Faculty of Animal Husbandry Non Ruminants Nutrition Laboratory, the Laboratory of Biotechnology and Microbiology, and the Faculty of Medicine at Andalas University, Padang.

\subsection{Making Buffalo Curd and Sensory Analysis}

Buffalo milk was pasteurized at a temperature of $60-75{ }^{\circ} \mathrm{C}$ for 30 minutes, then cooled to room temperature $(25){ }^{\circ} \mathrm{C}$. The milk was then put into clean bamboo tubes. The bamboo tubes were closed and tied with plastic to allow the milk to ferment for $24-48$ hours at $25{ }^{\circ} \mathrm{C}$. Dadih was obtained when buffalo milk clumped to form a dense and white consistency. After consistency, organoleptic (hedonic) test was conducted by 30 semi-trained panelists from the community (pregnant women) in Bukittinggi and Agam on the nature of taste, color, aroma, texture, and general acceptance of dadih on a scale of $1=$ dislike, $2=$ rather like, $3=$ ordinary/neutral, $4=$ like, and $5=$ highly like.

\subsection{Proximate Composition}

The protein content of dadih samples was determined by using the kjeldhal method. The total lipid was extracted with hexane by using the soxhlet method. The moisture value was evaluated by using the oven drying method, the ash content was determined by using the furnace incineration method (AOAC, 2000). The difference method was used to calculate the carbohydrate by subtracting $100 \%$ crude protein, fat, moisture, and ash content. The first step for sample $\mathrm{pH}$ measurement i.e., three grams $(3 \mathrm{~g})$ of sample blended with $3 \mathrm{~mL} \mathrm{dH} 2 \mathrm{O}$ in a beaker was determined by using a pH meter (Jenway 3310, England). $\mathrm{pH}$ meter was calibrated with $\mathrm{pH} 4.0$ and $\mathrm{pH} 7.0$ buffer solution before the measurement. Titratable acidity began with the measurment of ten samples $(10 \mathrm{~mL})$ and three drops of $0.1 \mathrm{~N}$ phenolphthalein indicator added. The mixture was titrated against $0.1 \mathrm{~N} \mathrm{NaOH}$ until the first permanent pink color appeared. The titrated acidity was then calculated and expressed as percent lactic acid.

\subsection{Microbiological Analysis}

The population of Lactic Acid, aerobic, and E. choli (cfu/mL) bacteria was determined by using MRS agar media (Oxoid, England), plate count agar (PCA) (Oxoid, England), and endo agar. (Oxoid, England). A total of $5 \mathrm{~g}$ of dadih samples from Agam and Tanah Datar was taken aseptically and put into a sterile tube containing $45 \mathrm{~mL}$ of buffered peptone water (Oxoid, England) $0.1 \%$ sterile. The samples were made into several serial dilutions, then planted on MRS media to allow the media, plate count agar (PCA), and endo to beububate by using an incubator (Memmert, Germany) at $37^{\circ} \mathrm{C}$ for $24-48 \mathrm{~h}$. The microbial colonies formed were calculated based on the Standard Plate Count (SPC) with the following formula: 


$$
\text { Total Population }(\mathrm{cfu} / \mathrm{ml})=\frac{\mathrm{N} \text { cawan }}{(\mathrm{n} 1+(0,1 \times \mathrm{n} 2)) \times \mathrm{d}}
$$

Notes:

$\mathrm{N}=$ Number of different colonies in the count range (25-250 colonies).

$\mathrm{n} 1=$ The number of the first cup whose colonies can be counted.

n2 $=$ Number of second cups whose colonies can be counted.

$\mathrm{d}=$ The first dilution calculated.

\subsection{Selection of Respondents and Socialiszation}

This research was conducted with the approval of Research Ethics Commission of the Faculty of Medicine Andalas University. Initial screening was conducted to find prospective respondents i.e., two trimesters gestational age pregnant women in Bukittinggi and Agam districts. The respondent criterion consists of volunteer women having a $12-16$ weeks gestational age, $\mathrm{Hb} \geq 10$, and who were not suffering from anemia and chronic diseases. This study is aimed to identify changes as a result of the intervention with an $\alpha=0,05,1-\beta=0,8$, a difference in birth weight (0.3) of infants in accordance with the result of intervention studies in Indonesia (Dijkhuizen, 2001). The sample size is calculated by using sample size formula hypothesis testing between two means (Lemeshow, 1990).

$$
\mathrm{n}=\frac{2 \sigma^{2}\left(z_{1-\alpha / 2}+z_{1-\beta}\right)^{2}}{\left(\mu_{1}-\mu_{2}\right)^{2}}
$$

Note:

$\mathrm{n} \quad=$ number of sample size

$Z_{1-\alpha / 2}=Z$ score for significance level of $\alpha$ in two sided hypothesis testing (5\%)

$Z_{1-\beta}=Z$ score for $1-\beta$ power of statistical test $(80 \%)$

$\sigma^{2}=$ Population Variance

$\mu 1=$ Test value of population mean

$\mu 2=$ Anticipated population mean

\subsection{Product Intervention}

The intervention stage is the stage of giving dadih regularly to the respondent's house for \pm 156 days (in the second trimester of pregnancy to delivery) except in the control group. Packed in bamboo tubes, the products were administered to each respondent every day except Sunday. The treatment was carried out on three groups, namely dadih, dadih + zinc, and control group. Every pregnant woman in the intervention group received 100 grams of dadih and $20 \mathrm{mg}$ of sulfate zinc supplement every day for 6 months. Pregnant women in the control group did not receive treatment from researchers but their received intervention at Community Health Centers or Pusat Kesehatan Masyarakat (Puskesmas) through their routine programs. Fruit tastes or spicy sugar was added to dadih to make it more attractive. Monitoring of acceptance and consumption compliance were conducted every week. Nutrition education was given every month during the study. Health checks for pregnant women were carried out in accordance with ANC procedures by each Puskesmas.

\section{Results and Discussion}

\subsection{Characteristics of Dadih}

The dadih used in this study originates from Agam and Tanah Datar regions. It is made by buffalo farmers in accordance with the standards set by the researchers. Until recently, farmers used to process dadih in a less hygienic way because of their limited knowledge. In this research, farmers were trained to make more hygienic dadih by paying attention to buffalos, equipment and workers sanitation. In addition, farmers were also taught how to pasteurize buffalo milk so as to kill pathogenic bacteria by heating milk at a temperature of $62-65^{\circ} \mathrm{C}$ for 30 minutes. Dadih is fermented for $\pm 24-48$ hours and takes the shape of a lump that condenses like tofu. It has a white color and smells like sour milk. According to Sirait (1993), a good dadih is white with a consistency resembling acidic milk. Sisriyenni and Zurriyati (2004) report that white dadih that has soft texture with a specific aroma is preferred by consumers. The consistency of dadih is influenced by its chemical components such as protein, fat, water, and lactic acid bacteria produced from the fermentation process of milk. The fermentation process involves Lactobacillus bacteria naturally found in milk. These bacteria produce B-galactosidase which will break down lactose into glucose and galactose. Glucose is changed to fructose 6-phosphate through the process of glycolysis. The end result of the glycolysis process is lactic acid formation (Horton et al., 2012). 


\subsection{Sensory Evaluation}

Sensory test results on the color, aroma, taste, texture, and general acceptance of buffalo dadih from Tanah Datar and Agam are presented in Figure 1. Based on the scores given by the panelists, Tanah Datar dadih sample was preferred by the panelists with a mean value of $4.53 \%$ common acceptance preference. The results of sensory value analysis showed that there was a significant difference between color, taste, texture and general acceptance between dadih from Tanah Datar and that of Agam with a value of $p<0.05$. However, in the panoramic assessment, there was no significant difference between both in terms of aroma (with $\mathrm{p}>0.05$ ( $\mathrm{Pv}$ value 0.184 ).

A significant difference between Tanah Datar dadih and that of Agam, in terms of color, taste, texture and general acceptance indicates that Tanah Datar dadih is preferred by panelists to that of Agam. This is due to the fact that the former has a slightly whiter color, less acidic taste and a soft texture like a pudding. This is allegedly caused by the quality of milk used (Afdi, 2006). Milk quality is affected by animal feed. Tanah Datar buffalos are is fed with banto grass and additional supplements in the form of napal powder, while Agam buffaloes are fed with grass weeds. A buffalo can produce milk at 5 months of pregnancy, and at the time of birth of the cald ( 2 months old). The characteristics of superior dadih-producing buffaloes include large body, a large milk bag and fall, and upwards curved horns

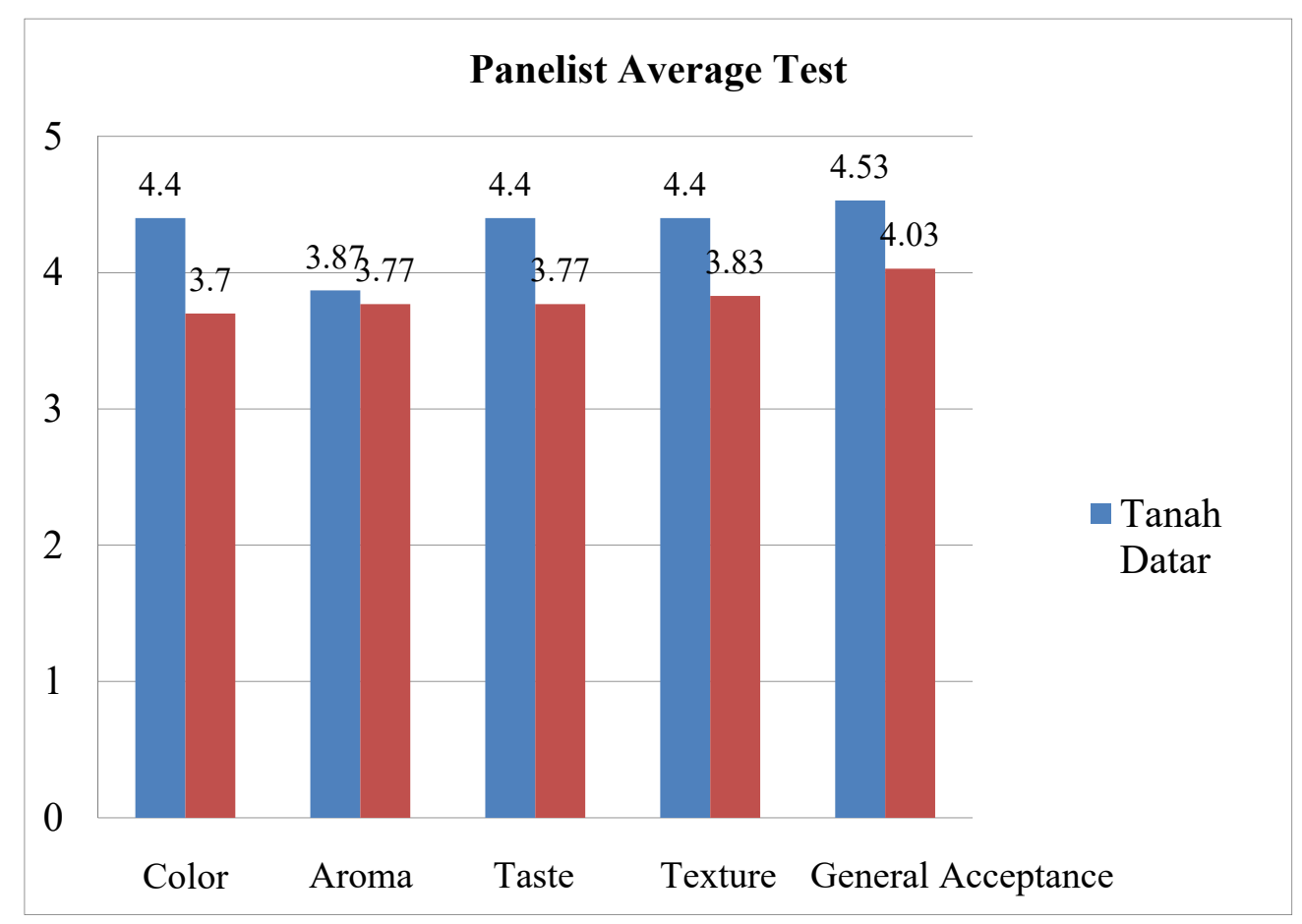

Figure 1. Panelist Average Test Value of dadih from Tanah Datar and Agam

The average buffalo can produce milk for \pm 3 months. The average milk produced from 1 buffalo is $2-3$ liters per day (in the productive period that is after the buffalo gives birth). Buffalo pregnancy period varies depending on the sex of the child being conceived. The age of buffalo pregnancy containing male buffalo is 11 months, while the age of the female buffalo is 10 months. Buffalo can be mated again after 1-2 months after giving birth. One way to allow buffaloes to reproduce is to feed them with additional food, namely palm sugar water.

\subsection{Proximate Analysis}

Proximate analysis carried out on dadih sample aims to determine the levels of protein, fat, water, ash, crude fiber, carbohydrate, $\mathrm{pH}$, and acidity contained in the sample. Results of the observations of proximate analysis can be seen in Table 1. 
Table 1. Results of West Sumatran Dadih Chemical Analysis

\begin{tabular}{lll}
\hline \multirow{2}{*}{ Characteristics } & \multicolumn{2}{l}{ Source of Dadih } \\
\cline { 2 - 3 } & Tanah Datar & \\
\hline Protein (\%) & $12.41 \pm 1.30$ & Agam $^{1}$ \\
Fat (\%) & $5.70 \pm 1.73$ & $10.89 \pm 2.55$ \\
Water content (\%) & $66.09 \pm 6.00$ & $18.00 \pm 14.65$ \\
Ash content (\%) & $0.72 \pm 0.13$ & $61.94 \pm 20.18$ \\
Carbohydrate (\%) & $14.92 \pm 6.53$ & $1.14 \pm 0.79$ \\
pH & $4.55 \pm 0.21$ & $8.03 \pm 5.15$ \\
Acidity (\%) & $0.51 \pm 0.56$ & $4.33 \pm 0.46$ \\
\hline
\end{tabular}

Note. ${ }^{1}$ Chemical characteristics of Agam dadih are the average of the results of test of Palupuah and Gaduik regions dadih.

${ }^{2}$ Chemical characteristics of Tanah Datar dadih are the results of Padang Panjang dadih test.

The results showed that the $\mathrm{pH}$ value of dadih samples taken from Agam is lower than that of Tanah Datar. This is inversely proportional to the acidity level, where Agam dadih sample has a higher acidity value than Tanah Datar dadih. The lower the $\mathrm{pH}$ value produced shows the higher the acidity of the product. High acidity of Agam dadih samples illustrates that it has has a higher lactic acid content compared with Agam dadih samples (Table 1). The low $\mathrm{pH}$ value and the high level of acidity of Agam dadih are also thought to be caused by the type of buffalo food grass given. Agam dadih is produced from buffaloes fed with grass (Imperata cilindrica), while Tanah Datar dadih is produced from buffaloes fed banto grass and rice straws. It is known that weeds contain several acidic compounds namely malic acid and citric acid. It is suspected that these two compounds contribute to the flavor of Agam dadih's acid. The type of bamboo tube used as a container/packaging affects the chemical characteristics and water content of dadih. Agam dadih's water content (61.94\%) is lower than that of Tanah Datar (66.09\%). Agam dadih is packaged in Talang bamboo tube while Tanah Datar dadih is packed in Lapoh. Because Talang bamboo is bigger and thicker than Lapoh bamboo, its porosity is higher. Water or other liquid components can seep into it more easily. Nutrition given to buffalo also affects the chemical characteristics of dadih, including the levels of protein and calcium. Based on Table 1, it was found that the protein content of the analyzed samples is high at $10.89 \%$ in Agam dadih samples and $12.41 \%$ in Tanah Datar dadih samples. The protein content of Tanah Datar dadih is higher than that of Agam dadih. This is allegedly caused by the food supplements (Napal stones) given to buffaloes belonging to Tanah Datar farmers. Napal stone, usually called limestone, is calcium carbonate $\left(\mathrm{CaCO}_{3}\right)$ rich in mud or mudstone containing a variable number of clay and aragonite.

The results of the study (Table 1) show that the protein content of both Tanah Datar and Agam dadih samples is higher (6.5\%) than the protein content of dadih collected by Soenarto et al., (2013) from several locations of dadih production. Based on the results of the proximate analysis (Table 1), it was found that Tanah Datar and Agam dadih contain various nutrients needed by the human body. The weight of Tanah Datar and Agam dadih's macro nutrients can be calculated by using atwoter 4: 4: 9 conversion (carbohydrates: protein: fat). That is, every 1 gram of carbohydrate is equivalent to $4 \mathrm{kcal}$, protein equals $4 \mathrm{kcal}$, and the fat is equivalent to $9 \mathrm{kcal}$. The results of the calculation of dadih macro nutrition values are presented in Table 2 .

Table 2. Dadih Nutritional Components per 100 grams

\begin{tabular}{llllll}
\hline & & & & \\
No & Source Dadih & Calorie & Protein & Fat & Carbohydrate $(\mathrm{g})$ \\
& & $(\mathrm{Kal})$ & $(\mathrm{g})$ & $(\mathrm{g})$ & 59.68 \\
\hline 1 & Tanah Datar & 160.62 & 49.64 & 51.30 & 32.12 \\
\hline
\end{tabular}

\subsection{Microbiological Analysis}

Microbiological analysis carried out on the sample is aimed to determine the content of lactic acid bacteria, total 
plate count, and E. choli bacteria contained in the sample. The results of microbiological analysis observations can be seen in Table 3 .

Table 3. Results of the Microbiological analysis of dadih fromTanah Datar and Agam

\begin{tabular}{llll}
\hline Samples & $\begin{array}{l}\text { Lactic Acid Bacteria } \\
(\mathrm{cfu} / \mathrm{g})\end{array}$ & $\begin{array}{l}\text { Total Plate Count } \\
(\mathrm{cfu} / \mathrm{g})\end{array}$ & $\begin{array}{l}\text { E. choli bactery } \\
(\mathrm{cfu} / \mathrm{g})\end{array}$ \\
\hline Tanah Datar dadih & $1.9 \times 10^{7}$ & $2.3 \times 10^{7}$ & - \\
Agam dadih & $4.6 \times 10^{6}$ & $2.9 \times 10^{8}$ & - \\
\hline
\end{tabular}

The results show that Tanah Datar dadih contains lactic acid bacteria estimated to $1.9 \times 107 \mathrm{cfu} / \mathrm{g}$, which is higher than the lactic acid bacteria in Agam dadih (4.6 x $106 \mathrm{cfu} / \mathrm{g})$. The growth of bacteria in dadih is affected by nutrients, water, and temperature. The bamboo used as a dadih packaging is thought to contain a substrate that can supports the growth of lactic acid bacteria. Lactic acid bacteria are homofermentative bacteria belonging to mesophilic bacteria and have an optimum a temperature range for growth and development of $20-45^{\circ} \mathrm{C}$ (Surono, 2016). Dadih, as a functional food, contains lactic acid bacteria that act as probiotics which is beneficial to human health (Hutami et al., 2013). The role of lactic acid bacteria is not only to regulate the digestive tract ecosystem, but it also contributes in the formation of texture of dadih. The lactic acid produced by bacteria can inhibit the growth of other harmful bacteria, such as bacterium E. choli, which causes diarrhea. Dadih mainly consists of buffalo milk by relying on microorganisms in nature as inoculants without using an additional starter. These microbes are thought to come from bamboo tubes used as containers (Zakaria et al., 2002), and from the banana leave tube covers or from the milk itself (Afdi, 2006). Probiotics are living microorganisms, which, when given in sufficient quantities provide health to their hosts (FAO and WHO, 2002). Probiotic bacteria are able to overcome saliva, stomach acid and bile obstacles during the journey to the digestive tract. These bacteria can survive in the digestive tract ecosystem, enabling them to reach a certain amount for a certain time. The amount/viability of probiotic microbes after going through the digestive tract ranges between 106-107 cfu/g mucosa (Bouhnik, 1993).

Probiotic bacteria can improve the health of the host's body through several ways, including by producing antimicrobial compounds such as lactic acid, $\mathrm{H}_{2} \mathrm{O}_{2}$, bacteriocin, renterin and compounds that inhibit the growth of pathogenic bacteria, stimulate the immune system and are able to change the activity of microbial metabolism in the digestive tract, and excel in competition to attach to fine epithelial cells and absorb nutrients needed by the body.

\section{Conclusion}

Dadih is a fermented buffalo milk that contains macro nutrients such as protein, fat, carbohydrates, and water. In addition, dadih also contain probiotics that are good for human health. This dairy product typical of West Sumatra can be found mostly in Tanah Datar and Agam regions. The dadih from Tanah Datar contains $12.41 \pm 1.30 \%$ protein, $5.70 \pm 1.73 \%$ fat, $14.92 \pm 6.53 \%$ carbohydrate, and $66.09 \pm 6.00 \%$ water. Meanwhile, dadih from Agam contains $10.89 \pm 2.5 \%$ protein, fat $18.00 \pm 14.65 \%$, carbohydrate $8.03 \pm 5.15 \%$, and water $61.94 \pm 20.18 \%$. both dadih contain lactic acid bacteria with a number of $1.9 \times 107 \mathrm{cfu} / \mathrm{g}$ in dadih from Tanah Datar and 4.6 x $106 \mathrm{cfu} / \mathrm{g}$ in dadih from Agam. Daih is very good for lactose intolerance sufferers. This is because lactic acid bacteria contained in dadih can inhibit the growth of E. choli bacteria which can cause diarrhea. Consumption of dadih can increase one's nutritional intake. Based on the research, it is known that dadih from Tanah Datar can provide $160.62 \mathrm{Kal}, 49.64 \mathrm{~g}$ of protein, $51.30 \mathrm{~g}$ of fat, and $59.68 \mathrm{~g}$ carbohydrates. While Dadih from Agam can provide $237.68 \mathrm{Kal}$, protein $43.56 \mathrm{~g}$ protein, fat $162.00 \mathrm{~g}$, and $32.12 \mathrm{~g}$ carbohydrates. Nutritious dadih along with its benefits is still less attractive to the public, especially among young people because of its taste and smell. Therefore, it is very necessary to process dadih technologically in order to turn it into an attractive dairy product for everyone.

\section{Competing Interests Statement}

The authors declare that there are no competing or potential conflicts of interest.

\section{References}

Association of Analitycal Communities [AOAC]. (2000). Official Methods of Analysis of the Association of Official Analytical Chemistry (16th Ed.). AOAC International, Washington, USA. Pages: 1141.

Bacteriological Analytical Manual [BAM]. (2011). Aerobic Plate Count.]. Retrieved Agustus 08, 2017, from 
http://cfsan.Fdagov/abam/bam/Html

Bouhnik, Y. (1993). Survie et effets chez l'homme des bactéries ingérées dans les laits fermentés. Le lait, 73(2), 241-247.

Charteris, W. P., Kelly, P. M., Morelli, L., \& dan Collin, J. K. (1998). Ingredient selection criteria for probiotic microorganism in functional dairy food. Int. J. Dairy Tech., 51(4), 123-135. https://doi.org/10.1111/j.1471-0307.1998.tb02516.x

Horton, H. R., Moran, L. A., Ochs, R. S., Rawn, J. D., \& Scrimgeour, K. G. (2012). Principles of biochemistry (5 ${ }^{\text {th }}$ ed.). United Stated of America: Pearson.

Hutami, R., Aslimak, S., \& Andiyana, Y. (2013). Is ice cream contain dadih potential functional food?. In CISAKis the flagship conference of the Indonesian Students Association of Korea (No. 6, p. 76).

Lemeshow, S., Hosmer, D. W., Klar, J., Lwanga, S. K., \& World Health Organization. (1990). Adequacy of sample size in health studies.

Lutter, C. K., \& Chaparro, C. M. (2009). Neonatal period: Linking best nutrition practices at birth to optimize maternal and infant health and survival. Food and nutrition bulletin, 30(2_supp12), S215-S224. https://doi.org/10.1177/15648265090302S205

Pato, U. (2003). Potensi bakteri asam laktat yang diisolasi dari dadih untuk menurunkan resiko penyakit kanker. Jurnal Natur Indonesia, 5(2), 162-166.

Putra, A. A., Marlida, Y., Khasrad, K., Azhike, S. Y. D., \& Wulandari, R. (2011). Perkembangan dan usaha pengembangan dadih: sebuah review tentang susu fermentasi tradisional Minangkabau. Jurnal Peternakan Indonesia (Indonesian Journal of Animal Science), 13(3), 159-170.

Sirait, C. H. (1993). Pengolahan susu tradisional untuk perkembangan agroindustri persusuan di pedesaan. Balai Penelitian Ternak, Ciawi, Bogor.

Sisriyenni, D., \& Nasution, K. (2014). Kajian kualitas dadih susu kerbau di dalam tabung bambu dan tabung plastik.

Soenarno, M. S., Polii, B. N., Febriantosa, A., \& Hanifah, R. (2013). Identifikasi Peptida Bioaktif dari Olahan Susu Fermentasi Tradisional Indonesia sebagai Bahan Pangan Fungsional untuk Kesehatan. [Biopeptide Indentification of Indonesian Fermented and Processed Milk as Functional Food] . Jurnal Ilmu Produksi dan Teknologi Hasil Peternakan, l(3). Hlm: 191-195.

SSurono, I., Nishigaki, T., Endaryanto, A., \& Waspodo, P. (2008). IndonesianBiodiversities, fromMicrobes toHerbalPlants as Potential FunctionalFoods. Journal ofthe FacultyofAgriculture SHINSHU UNIVERSITY 44(1), 2.

Surono, I. S. (2016). Probiotik, Mikrobioe dan Pangan Fungsional. Yogyakarta: Deepublish.

Tannock, G. W. (1999). Probiotic: A Critical Review. Horizon Scientific Press, England.

Zakaria, Y. (2002). Aktivitas mitogen dari polysakorida yang diproduksi oleh bakteri asam laktat yang diisolasi dari dadih . Prosiding Seminar Teknologi (95-98).

\section{Copyrights}

Copyright for this article is retained by the author(s), with first publication rights granted to the journal.

This is an open-access article distributed under the terms and conditions of the Creative Commons Attribution license (http://creativecommons.org/licenses/by/4.0/). 